\title{
APROPRIAÇÃO DO ESPAÇO URBANO PELA CRIANÇA: A IMPORTÂNCIA DO JOGO LÚDICO
}

ANGELO SERPA

Pesquisador doutor do CNPqjunto ao Departamento de Projeto da Faculdade de Arquitetura e Urbanismo da Universidade de São Paulo e mestrado em geografia da Universidade Federal da Bahia. Engenheiro Florestal e Doutor em Planejamento Paisagistico e Ambiental pela Universidade de Agronomia de Viena, Austria. 


\section{RESUMO}

ara desenvolver-se e descobrir o mundo brincando, a criança precisa de um meio ambiente social aberto a novas experiências e ao mesmo tempo propício ao jogo lúdico. A situação real da criança no meio ambiente urbano se caracteriza, no entanto, pela carência crônica de espaços livres. Para entender melhor a segregaçãoespacial do atode brincar foram entrevistadas 37 crianças com idades entre 7 e 9 anos no bairro de Itaquera, na zona leste de São Paulo. As crianças desenharam comoe onde brincam mais nobairro. Foram realizadas também entrevistas estruturadas com os pais e mães de algumas crianças que se prontificaram a participar da pesquisa. Os espaços mencionados pelas crianças foram fotografados e comparados com os espaços desenhados. Para análise dos desenhos utilizou-se as categorias descritas por Jean Piaget para a classificação dos jogos e sua evolução. $O$ jogo lúdico parece obedecer ao desenvolvimento gradual proposto por Piaget, mas a segregação espacial do ato de brincar pode ocasionar uma certa renitência do símbolo deformante, que já deveria estar totalmente superado nesta fase do desenvolvimento da criança.

\section{ABSTRACT}

I

n order to develop and discover the world playing, the child needs a social environment opened to new experiences and at the same time favorable to the ludic game. However, the real situation of the child in the urban social environment is characterized by a chronic lack of open spaces. In order to have a better understanding of the spatial segregation in playing, 37 children going from 7 to 9 years of age have been interviewed in the suburb of Itaquera, East Zone of the São Paulo City. Children were asked to draw how and where they most played in the suburb. Also, parents of some of the children have been interviewed. Those spaces mentioned by the chidren have been photographed and compared to the drawings. For the drawings'analysis, we used categories described by Jean Piaget to rate the games and their evolution. The ludic game seems to follow the gradual development proposed by Piaget but the spatial segregation when playing may cause some resistance in the deforming sign, which was supposed to be completely overcome in this phase of the child's development. 


\title{
A CRIANÇA, O JOGO EO ESPAÇO DE BRINCAR
}

\begin{abstract}
A importância do ato de brincar para o desenvolvimento físico e espiritual da criança é inegável: o jogo é a expressão de vida da criança. É como ela se apropria progressivamente do mundo que a cerca.
\end{abstract}

Brincando, a criança ocupa-se de um pedaço do mundo real e pode se desenvolver fisica e espiritualmente. Experimentando e testando sua força física, bem como suas aptidões naturais durante $o$ ato de brincar, a criança vai adquirindo independência e confiança em si mesma. Também para o "digerir" de sentimentos como medo e insegurança, o jogo funciona como um universo lúdico alternativo, um despertar gradual da criança para o mundo à sua volta.

Crianças e adultos apresentam diferenças qualitativas e quantitativas no seu sistema cognitivo. O desenvolvimento do sistema cognitivo é consolidado em fases diversas que se sucedem em uma seqüência lógica. Nenhuma criança atinge a fase " $X$ " sem ter passado pela fase " $\mathrm{X}-1$ "1

Se uma reação específica não foi adquirida na fase correspondente será cada vez mais difícil assimilar outras formas de reação associadas com as fases seguintes ${ }^{2}$. As fases estão interligadas por um mecanismo regulador de desenvolvimento e transformação, que se baseia em dois processos distintos denominados assimilação e acomodação. O processo de assimilação determina a incorporação de novas experiências ao sistema cognitivo do sujeito. O processo de acomodação molda, por seu lado, as estruturas cognitivas ao mundo real, com o objetivo de facilitar a sua compreensão.

Assimilação e acomodação acontecem simultaneamente e o desenvolvimento gradual do sistema cognitivo exige coordenação constante desses dois processos. Essa coordenação visa o equilíbrio entre as informaçōes vindas do mundo "real" e 
aquelas vindas do mundo "cognitivo" de cada indivíduo. Representações cognitivas são "construídas" pelo sujeito de forma estável e, ao mesmo tempo, flexível. É o equilíbrio entre estabilidade e flexibilidade que determina o desenvolvimento do sistema cognitivo da criança.

"O desenvolvimento da criança depende de uma troca de informações constante com o seu meio ambiente social. Um progresso mais lento ou mais rápido depende portanto de como este meio ambiente social está organizado." ${ }^{13}$

Para desenvolver-se e descobrir o mundo brincando, a criança precisa de um meio ambiente social aberto a novas experiências e ao mesmo tempo propício ao jogo lúdico. A situação real da criança no meio ambiente urbano se caracteriza, no entanto, pela carência crônica de espaços "brincáveis" ("conquistáveis").

O risco de atropelamento, a violência ${ }^{4}$, o crescimento in interrupto das grandes cidades brasileiras e o conseqüente medo dos pais (muitas vezes justificável) limitam o espaço de brincar e trazem consigo uma redução drástica do campo de percepção da criança. Grandes avenidas, aumento do volume e fluxo de carros nas ruas, destruição dos poucos espaços livres existentes: o espaço de brincar torna-se cada vez mais restrito e segregado, verdadeiros guetos cercados de asfalto por todos os lados.

Todo ser humano precisa adquirir, durante a fase de socialização, na infância e na adolescência, competências e qualificações, que garantam sua entrada futura no mundo adulto como cidadão qualificado, capaz de agir, trabalhar e se locomover no meio social ao qual pertence. $O$ ato de brincar é para a criança o que o trabalho é para o adulto5. 


\section{A PESQUISA E O MÉTODO}

As seguintes questões nortearam a pesquisa descrita a seguir:

- Onde e como brincam as crianças na periferia de São Paulo?

- Até que ponto a segregação espacial do ato de brincar afeta o processo de socialização da criança?

- Como reverter este quadro de segregação?

Para responder essas questões, foi escolhido o bairro de Itaquera na zona leste de São Paulo. Nos meses de outubro e novembro de 1994, foram feitas visitas constantes ao bairro e a Escola Municipal Benedito Calixto. 37 crianças com idade entre 7 e 9 anos (primeira série) desenharam por solicitação do pesquisador os locais onde brincam mais no bairro e os jogos e brincadeiras por eles praticados no exercício cotidiano do ato de brincar.

Foram realizadas dez entrevistas estruturadas com os pais e mães de algumas das crianças, que se prontificaram a participar da pesquisa. Durante a entrevista os pais e mães responderam se trabalham fora, quando e com que freqüência saem com os filhos, aonde vão (parques, praças, clubes?), onde os filhos brincam e se estão satisfeitos com as alternativas de lazer existentes no bairro. Também foram fotografados os espaços livres existentes nas proximidades do local de moradia dos pais e mães entrevistados de modo a permitir uma comparação dos espaços desenhados pelas crianças e os espaços "reais" de lazer existentes.

Para análise dos desenhos utilizou-se a seguinte metodologia:

- Classificação das condutas lúdicas de acordo com as categorias descritas por Piaget $(1964)^{6}$ para a classificação dos jogos e sua evolução, a partir do aparecimento da linguagem: o exercício, o símbolo e a regra.

- Comparação do espaço desenhado pela criança com o espaço real, analisando a capacidade da criança de "mapear" seu espaço cotidiano. 


\section{O EXERCÍCIO, O SÍMBOLL E A REGRA}

Piaget (1964) distingue três grandes tipos de estruturas que caracterizam os jogos infantis e dominam a classificação de detalhe: o exercício, o símbolo e a regra.

"Certos jogos não supõem qualquer técnica particular: simples exercícios pōem em ação um conjunto variado de condutas, mas sem modificar as respectivas estruturas, tal como se apresentam no estado de adaptação atual (...) Por exemplo, quando o sujeito pula um riacho pelo prazer de saltar e volta ao ponto de partida para recomeçar etc., executa os mesmos movimentos que se saltasse por necessidade de passar para a outra margem; masfá-lo por mero divertimento enão pornecessidade de passar para a outra margem."7

Para Piaget o símbolo, ao contrário do jogo de exercício, que não requer pensamento nem qualquer estrutura representativa especificamente lúdica, implica a representação de um objeto ausente, "visto ser a comparação entre um elemento dado e um elemento imaginado, e uma representação fictícia, porquanto essa comparação consiste numa assimilação deformante. ${ }^{\text {" }}$

No processo de desenvolvimento da criança, uma terceira grande categoria sobrepōe-se aos jogos simbólicos: a dos jogos com regras. Ao invés do símbolo, a regra supõe, necessariamente, relações sociais ou interindividuais, mas "não é uma simples regra inspirada na vida moral ou jurídica etc., mas uma regra especialmente construída em função do jogo, embora possa conduzir a valores que o ultrapassam." 9

Piaget supõe uma evolução constante dos jogos lúdicos com o desenvolvimento da criança. Assim, os jogos de exercício, que até o aparecimento da linguagem permitem a consolidação dos poderes sensório-motores, dão lugar aos jogos simbólicos durante o segundo período de desenvolvimento da criança (1-6 a 7 anos): é o símbolo que fornece à criança os meios de assimilar o "real" aos seus desejos e aos seus interesses. 
O período entre 7 a 8 anos e 11 a 12 anos é caracterizado pelo declínio evidente do simbolismo, dando lugar quer ao jogo de regras, quer às construções simbólicas cada vez menos deformantes: "A criança de 7 anos abandona o jogo egocêntrico das crianças menores, em proveito de uma aplicação efetiva de regras e do espírito de cooperação entre os jogadores." 10

O que dizer então de Juliana ( 8 anos - Figura 1 e Fotos 1 e 2) que transforma o canteiro de couve da mãe em um canteiro de flores? Ou de Lucinéia (8 anos - Figura 2 e Foto 3) que anexa o quintal da tia ao quintal da sua residência, transportando a árvore da rua para os domínios da sua casa e fazendo "desaparecer" em seu desenho muros e cercas? Ou ainda de Bruno (9 anos Figura 3 e Foto 4) que transforma o quintal - estreito e comprido - de sua casa em um campo de futebol imaginário, demarcando-o e fazendo surgir em seu desenho traves e redes, ao mesmo tempo que omite (deliberadamente ou não) o muro, o gradil e a casinha do cachorro?

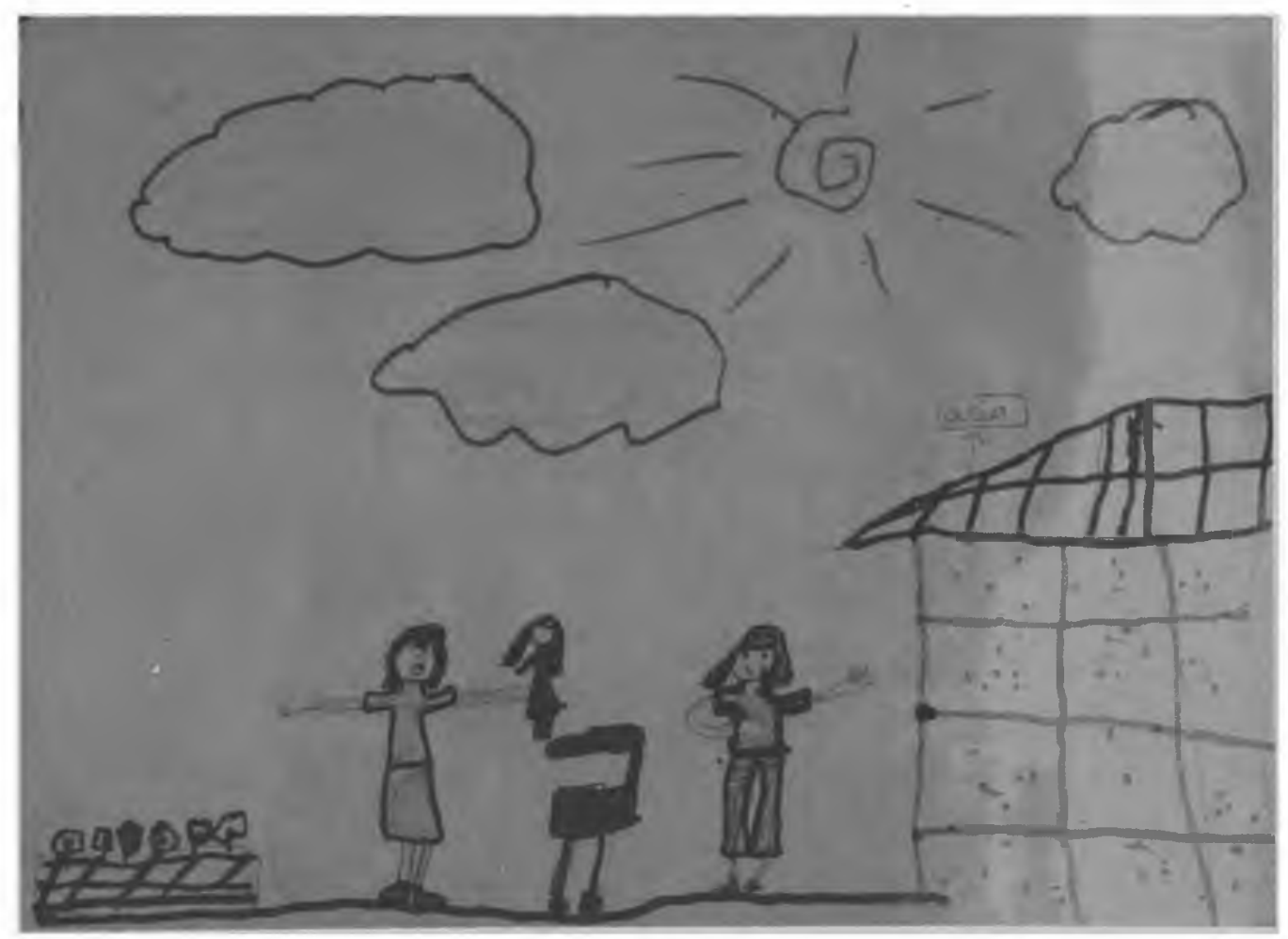

Figura 1: Brincando de boneca no quintal (Juliana, 8 anos). 


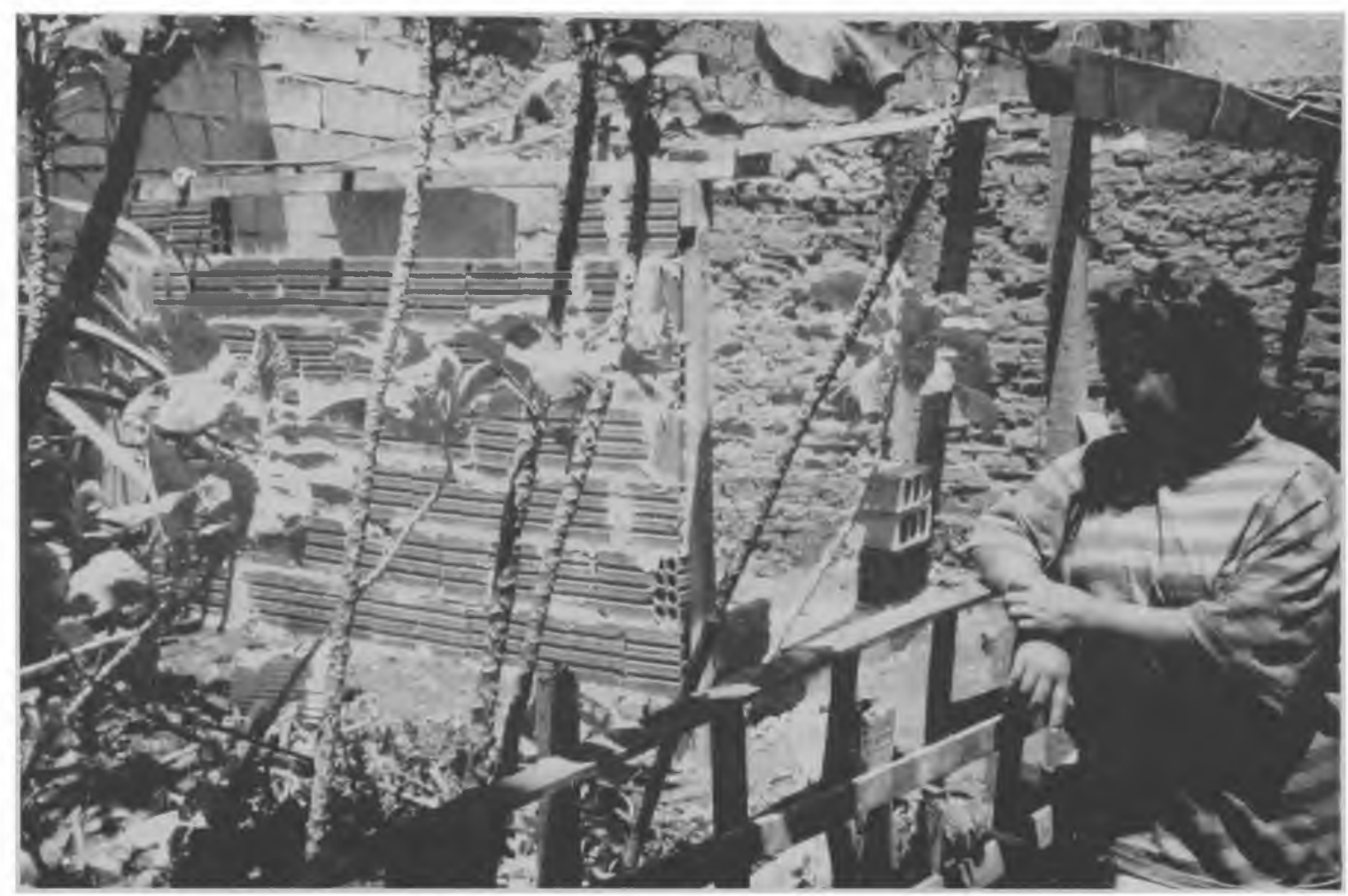

Foto 1: O canteiro de couve transforma-se em canteiro de flores (Foto: Angelo Serpa).

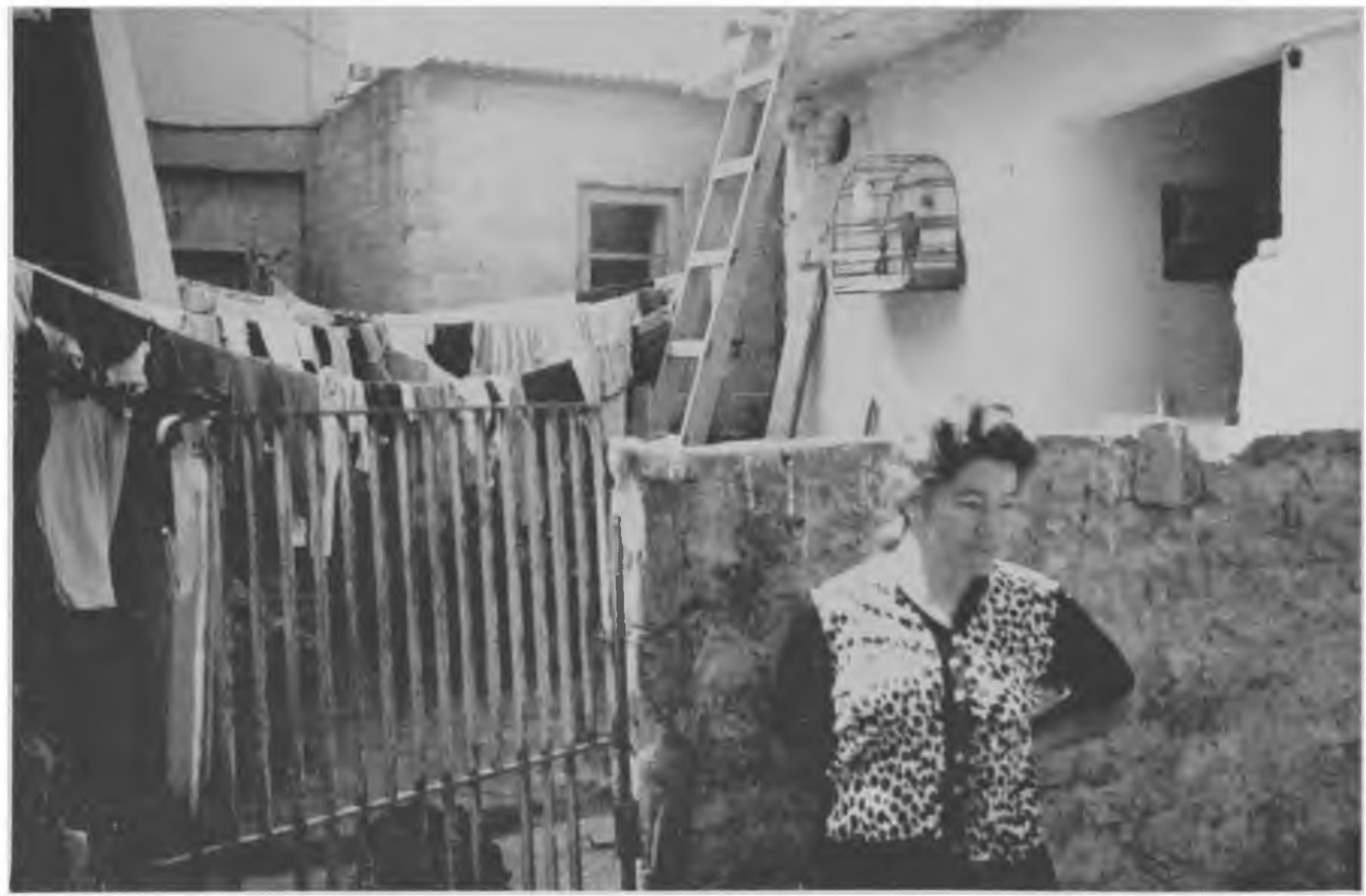

Foto 3: Fazendo desaparecer muros e cercas, Lucineia amplia o quintal de sua casa (Foto: Angelo Serpa). 


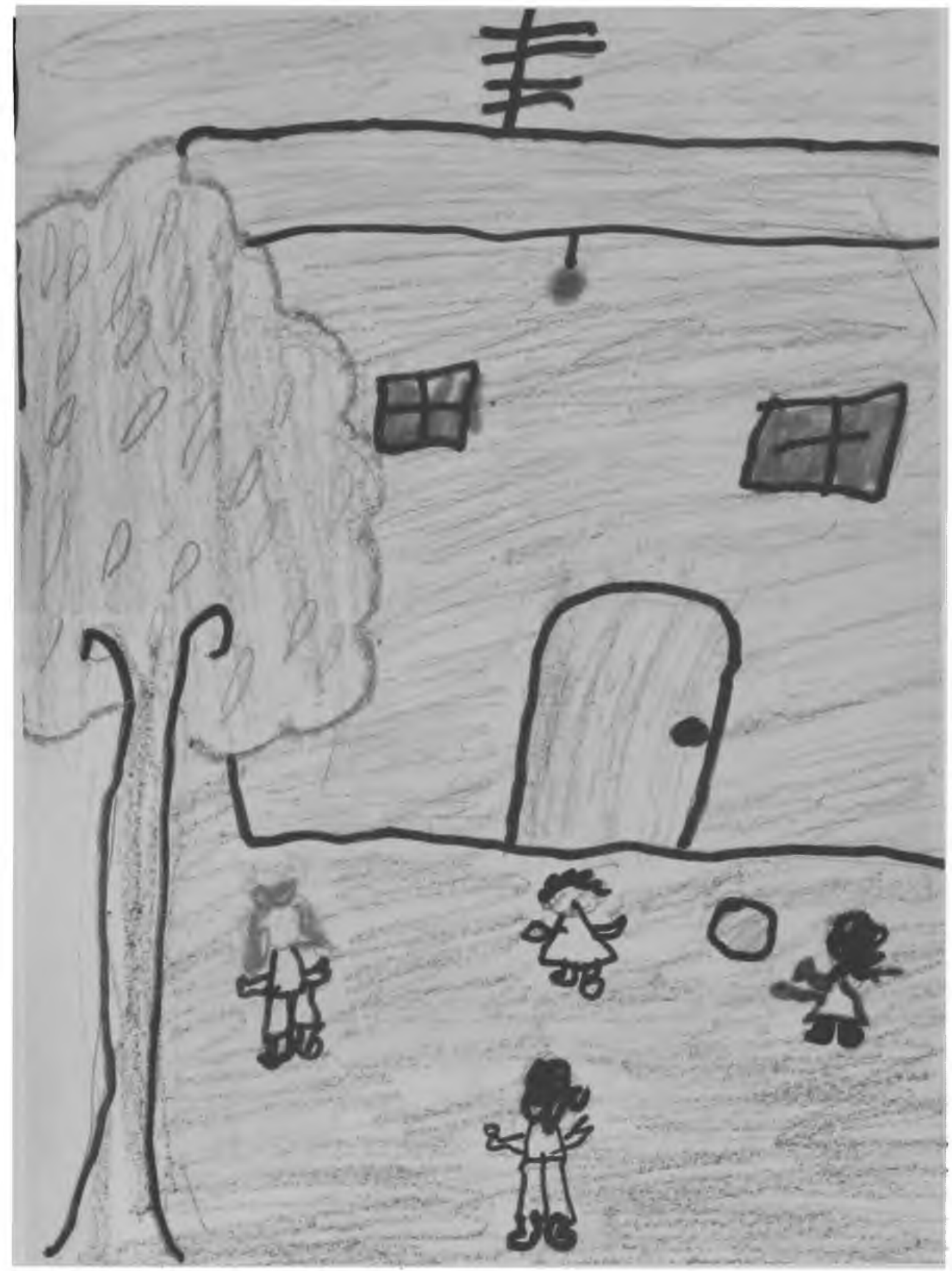

Figura 2: O quintal como quadra de vólei (Lucinéia, 8 anos). 


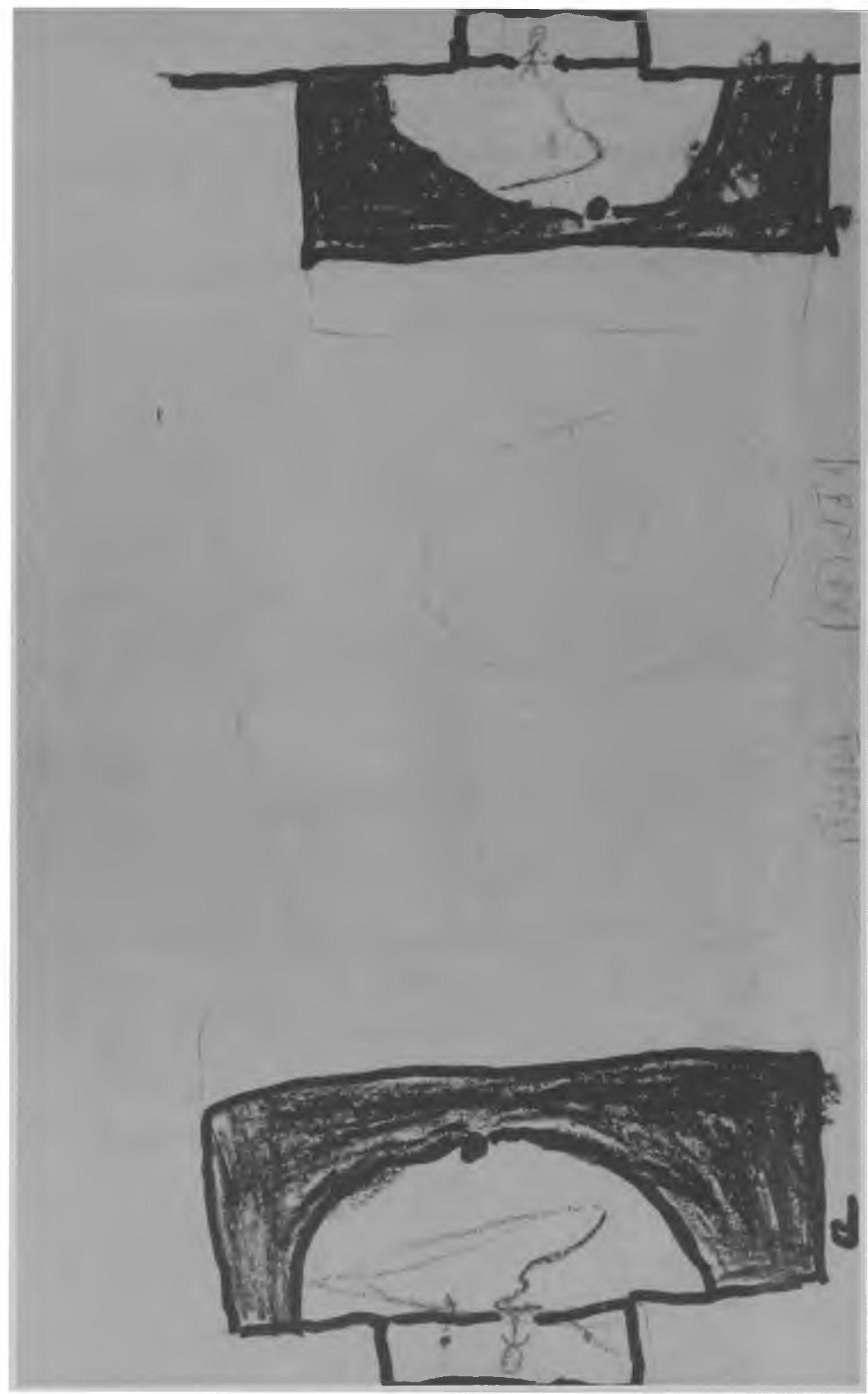

Figura 3: Jogando futebol (Bruno, 9 anos). 


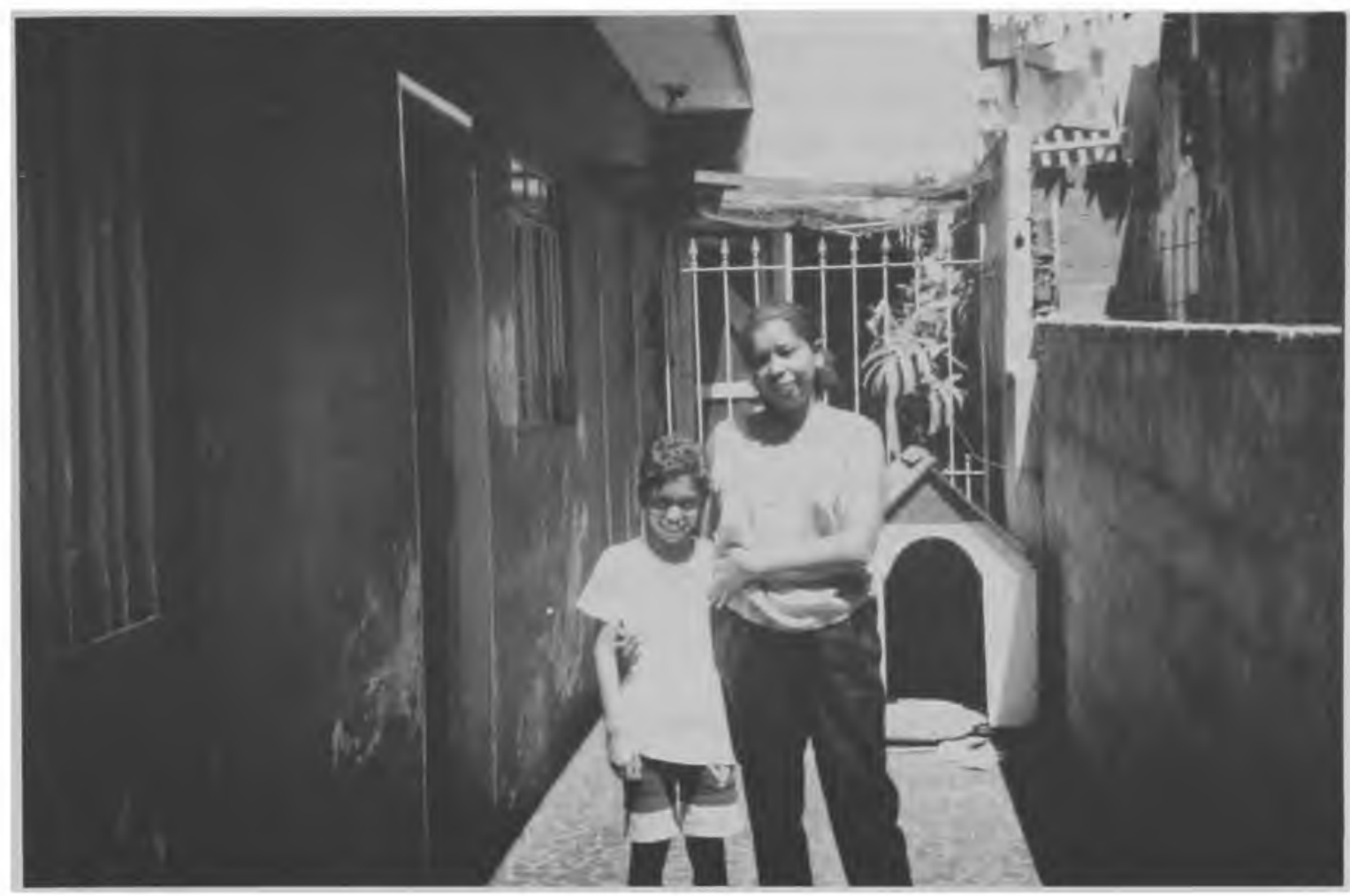

Foto 4: O quintal - estreito e comprido - transforma-se no desenho de Bruno em campo de futebol (Foto: Angelo Serpa).

Nota-se que as construções simbólicas nos três desenhos mencionados são ainda evidentemente deformantes. parecem querer expressar a necessidade de ampliação e "embelezamento" do espaço "brincável" $O$ jogo lúdico parece aqui ainda indispensável como meio de compensação ou mesmo liquidação do espaço real "experienciado" pelas crianças no ato cotidiano de brincar. Isso parece contradizer Piaget ao afirmar que quanto mais a criança se adapta às realidades físicas e sociais, menos se entrega às deformações e transformações simbólicas.

Uma análise mais acurada dos desenhos mostra, no entanto, um declínio do simbolismo nos jogos lúdicos propriamente ditos, já que o simbolismo compartilhado por muitos pode engendrar a regra (daí a transformação possível dos jogos de ficção em jogos de regras): Juliana brinca de "casinha", divide e representa "papéis" com a amiga, a boneca transforma-se evidentemente 
em filha, sobrinha, etc.; Lucinéia joga vôlei com três amiguinhas e Bruno compartilha o jogo de futebol com outra criança. Nos dois últimos casos além da regra, o exercício sensório-motor também se faz presente.

Essa constatação mostra-nos que, quando o símbolo vem-se inserir no exercício sensório-motor, não elimina este último e, pelo contrário, subordina-se-Ihe: "As suas funções afastam-se cada vez mais do simples exercício: a compensação, a realização dos desejos, a liquidação dos conflitos etc. somam-se incessantemente ao simples prazer de se sujeitar à realidade, a qual prolonga, por si só, o prazer de ser causa inerente ao exercício sensório-motor." 11

O surgimento da regra com o florescimento da socialização fica evidente nos desenhos de Talita (7 anos - Figura 4) e de Stanley (8 anos - Figura 5). A menina mostra uma sala de aula "fictícia" com quatro alunos, um deles sentado ao lado da professora, desproporcionalmente maior que os seus discípulos, e afirma brincar com freqüência de "escolinha" na sua casa: a "professora" desenha uma fada na lousa. O desenho do menino mostra diferentes jogos e esportes com regras: paredão, vôlei, basquete, beisebol, pega-pega, esconde-esconde, etc.; há a preocupação de mostrar com detalhes e de forma esquemática os jogos, representando em alguns casos o movimento da bola (vôlei, futebol).

Os dois desenhos mostram uma progressiva adaptação social já que em ambos a regra predomina. Talita, filha de professora primária, toma a mãe como símbolo (talvez por isso desenhando a "professora" muito maior que os alunos) e institui a regra da escola para o jogo de representação de papéis. Stanley incorpora ao exercício sensório-motor as regras dos jogos infantis consagrados pelas crianças mais velhas e dos esportes também praticados pelos adultos. Note-se que aqui a construção simbólica constitui apenas uma reprodução imitativa direta da realidade correspondente: o símbolo torna-se, portanto, imagem ${ }^{12}$. 


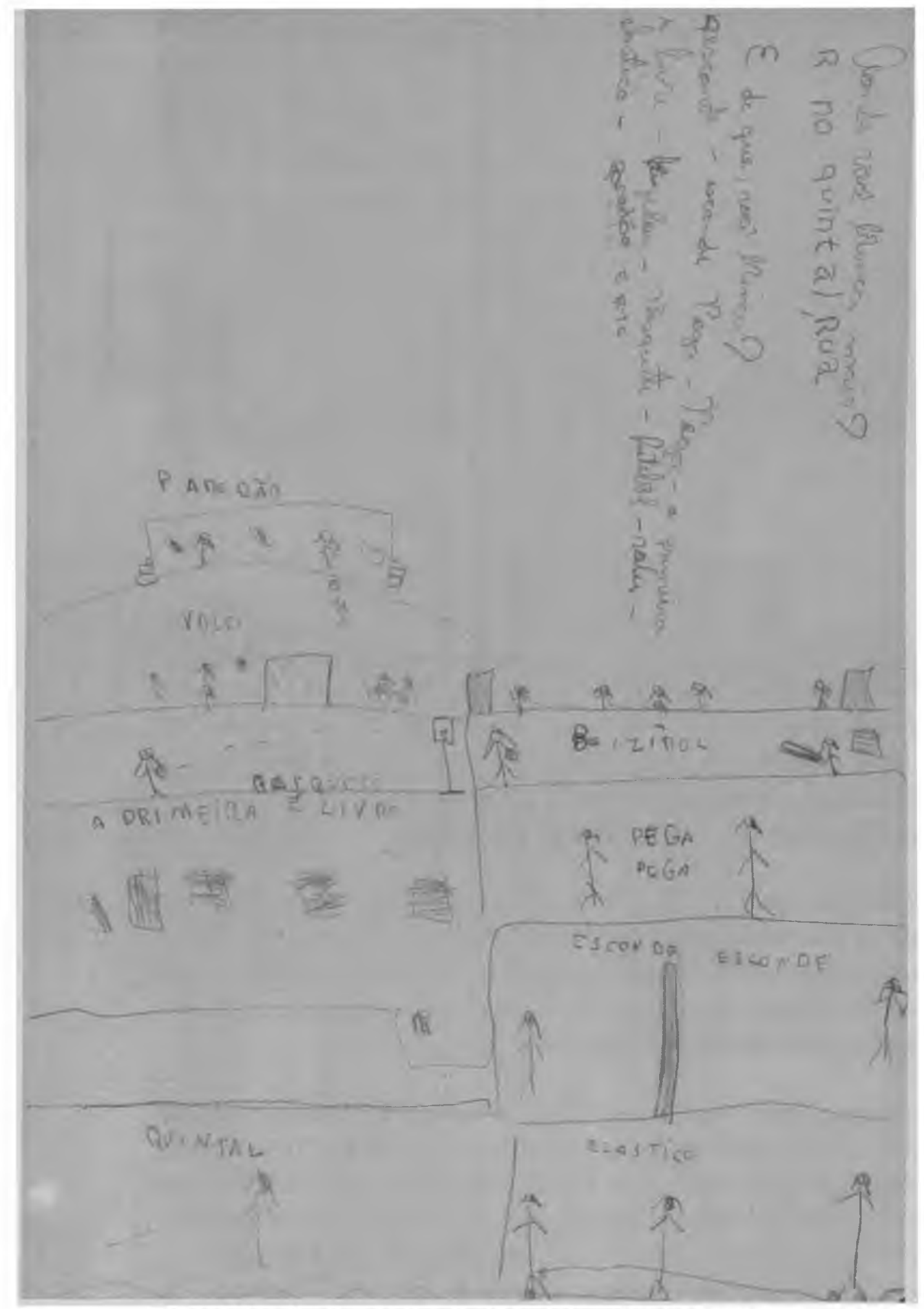

Figura 5: Paredão, pega-pega, esconde-esconde... (Stanley, 8 anos).

Paisagem Ambiente Ensaios São Paulo n. 8 p. 177 - 210 dez. 1995 


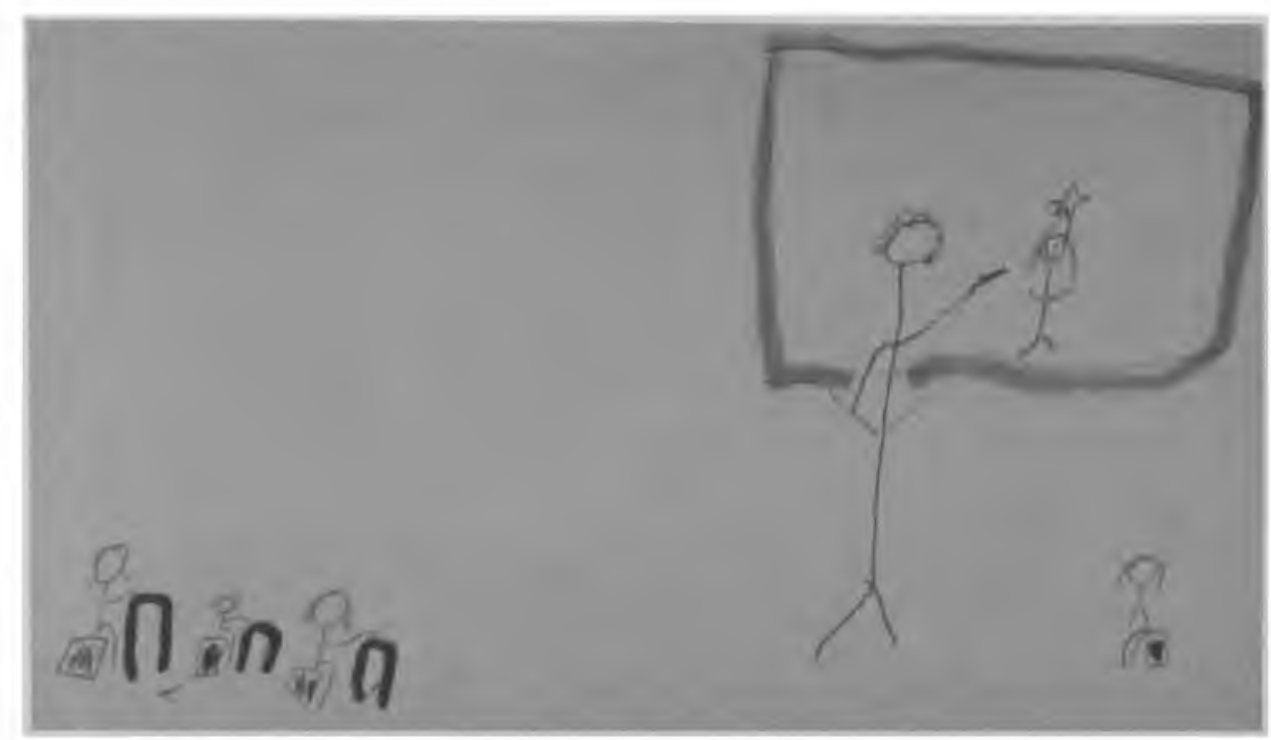

Figura 4: Brincando de "escolinha" (Talita, 7 anos).

\section{O ESPACCO INFANTIL E SUA REPRESENTAÇÃO GRÁFICA}

De acordo com Luquet (1927) ${ }^{13}$, a criança desenha - a partir dos 4 anos (fase que se estende até os 10 ou 12 anos) - não aquilo que vê, mas aquilo que sabe. Nesta fase as relações projetivas e euclidianas começam apenas a elaborar-se, enquanto as relações topológicas são em geral respeitadas.

"Uma vez constituídas as relações topológicas, a criança preocupa-se em respeitar as distâncias, as proporçōes respectivas das figuras; submete seu traçado à unidade de ponto de vista (...) daí o aparecimento da perspectiva, que não suplanta o espaço topológico, mas visa a integrá-lo." 14

Para representar o espaço a criança lança mão nessa fase de dois processos: o plano deitado e a transparência. No desenho de Bruno (Figura 3) p. ex. o campo de futebol é representado como se fosse visto de avião: no plano deitado os objetos não são representados em perspectiva, mas deitados em torno de um ponto ou eixo central. Tayane ( 9 anos Figura 6) desenha a fachada do prédio onde mora mas também o interior do seu apartamento, 
onde ela aparece brincando de "casinha": com o recurso da representação simultânea do objeto e de seu conteúdo (transparência), a casa é representada ao mesmo tempo de fora e de dentro ${ }^{15}$.

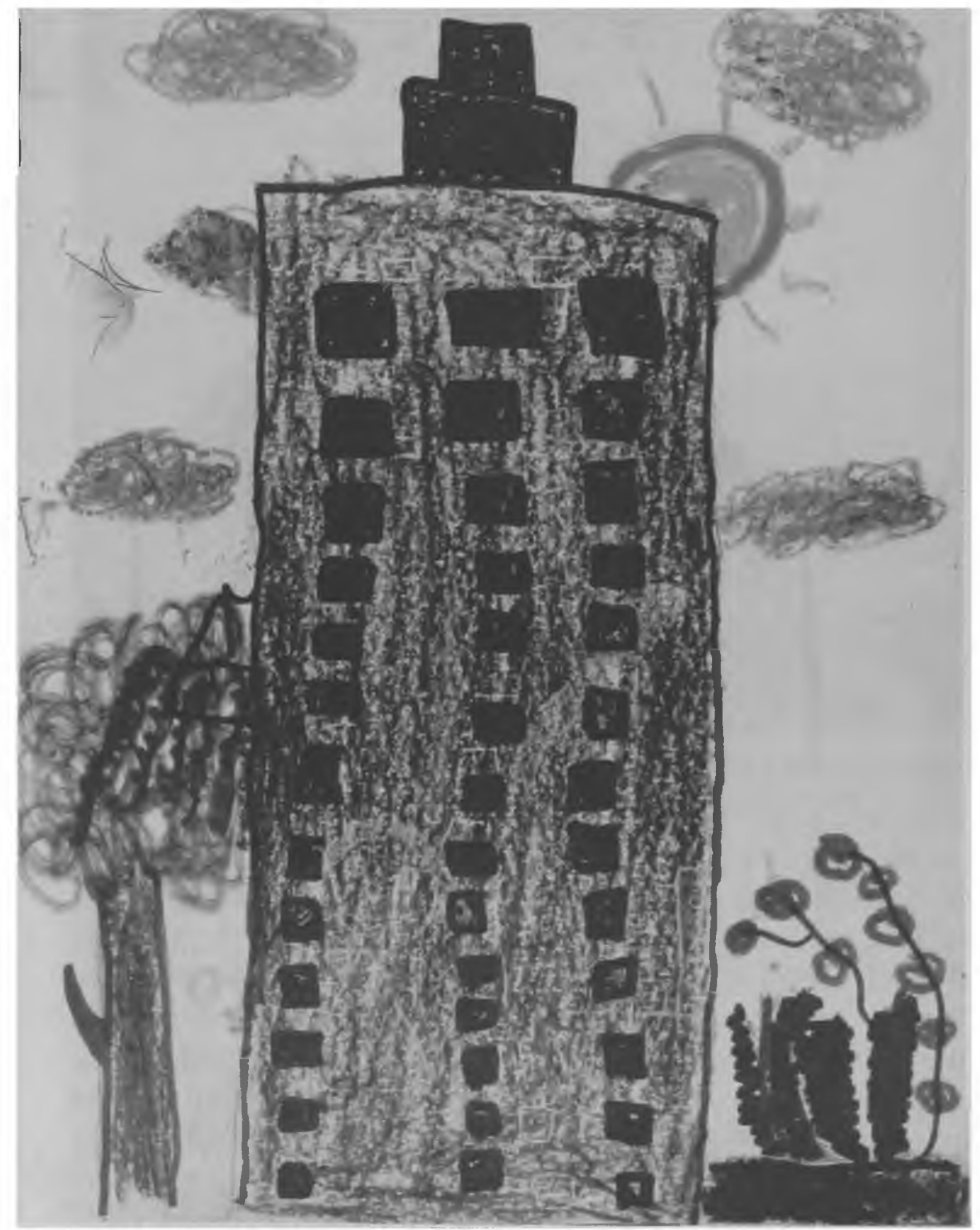

Figura 6: Fora, o prédio escuro. Dentro (Tayane, 9 anos). 


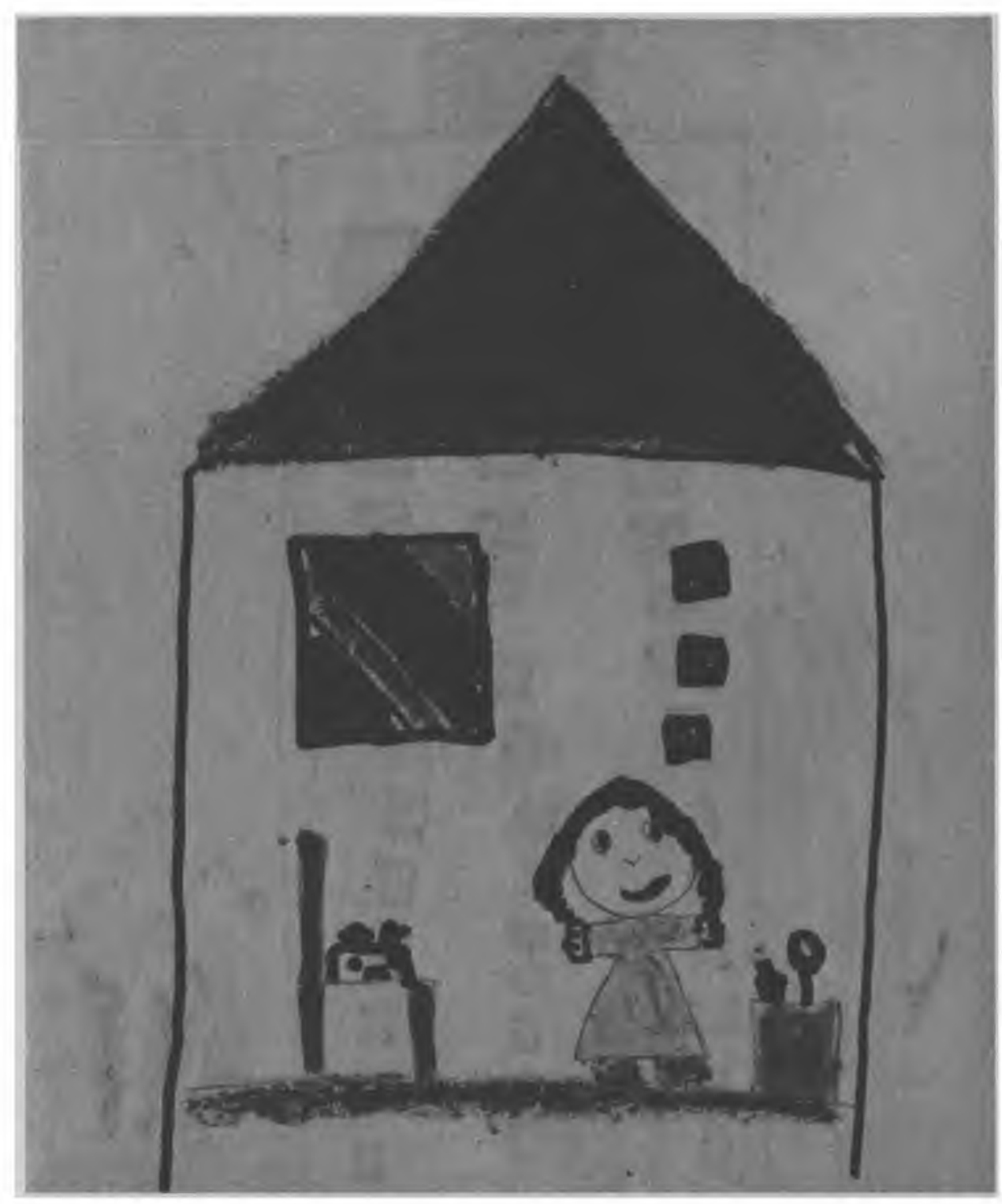

Figura 6A: A casinha de boneca (Tayane, 9 anos).

No desenho de Tayane o prédio onde reside adquire proporções muito maiores do que o prédio real (tem 14 andares, enquanto os edifícios da Cohab-Itaquera têm apenas seis - Foto 5). Everton (8 anos - Figura 7) respeita o número de andares do prédio, mas o representa desproporcionalmente maior que as duas crianças que brincam embaixo dele; há um retângulo negro na fachada verde do edifício, talvez querendo indicar a janela do seu apartamento, já que ele mora no quinto andar; observa-se também no desenho a ausência de perspectiva já que o prédio "flutua" no espaço, sendo apoiado por uma única coluna, que, na verdade, parece querer indicar a entrada do edifício. 
Vê-se, através dos dois exemplos acima, que, para a criança, a casa não é apenas o lugar onde os objetos se inscrevem, mas também uma rede de afetos: "A casa constitui para ela o mundo usual de sua experiência perceptiva e pragmática, cognitiva e afetiva, lugar em que se abrem os primeiros gestos, refúgio contra um universo desconhecido e ameaçador ${ }^{16}$."

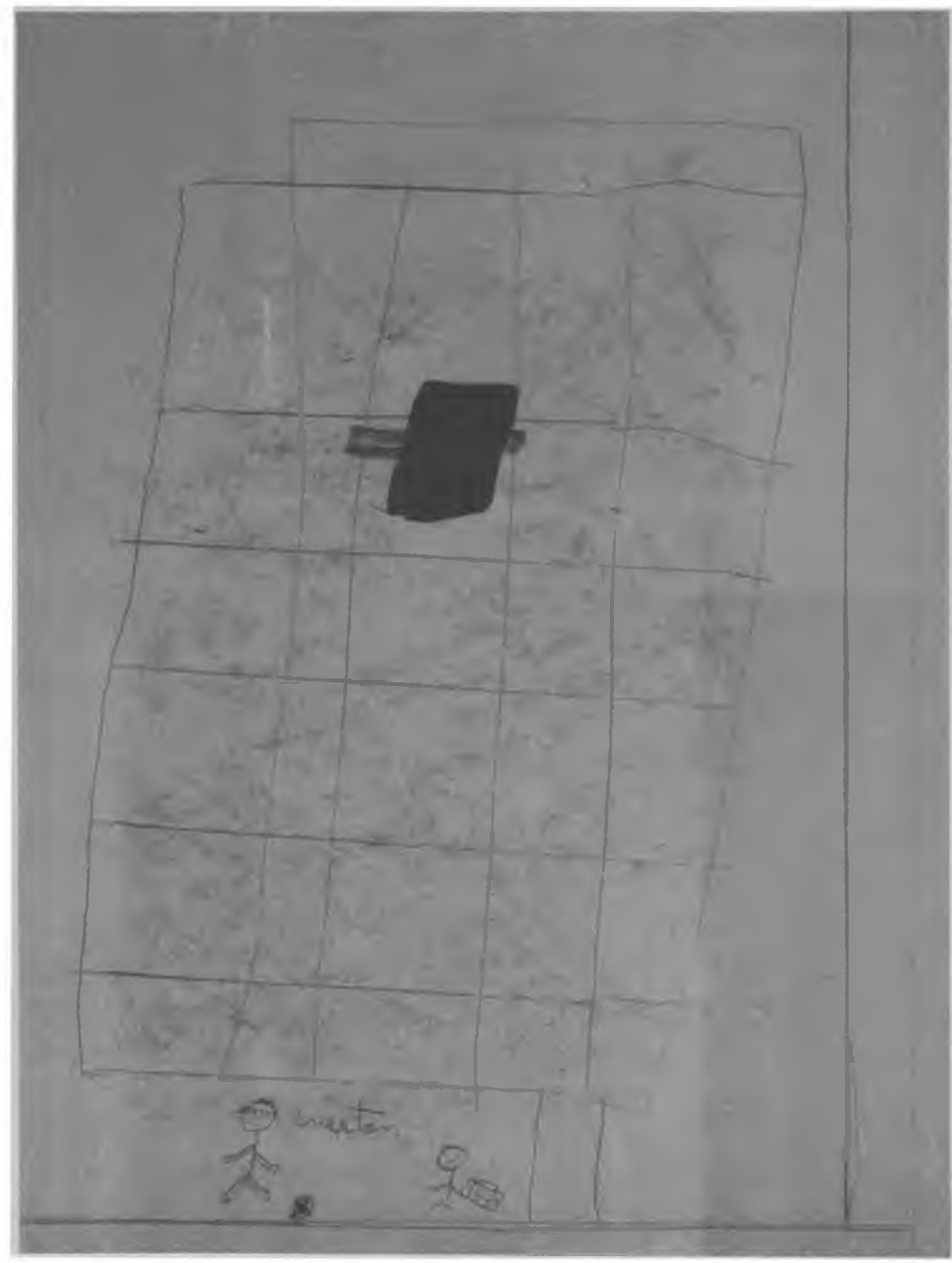

Figura 7: Brincando no pátio interno do prédio (Everton, 8 anos). 

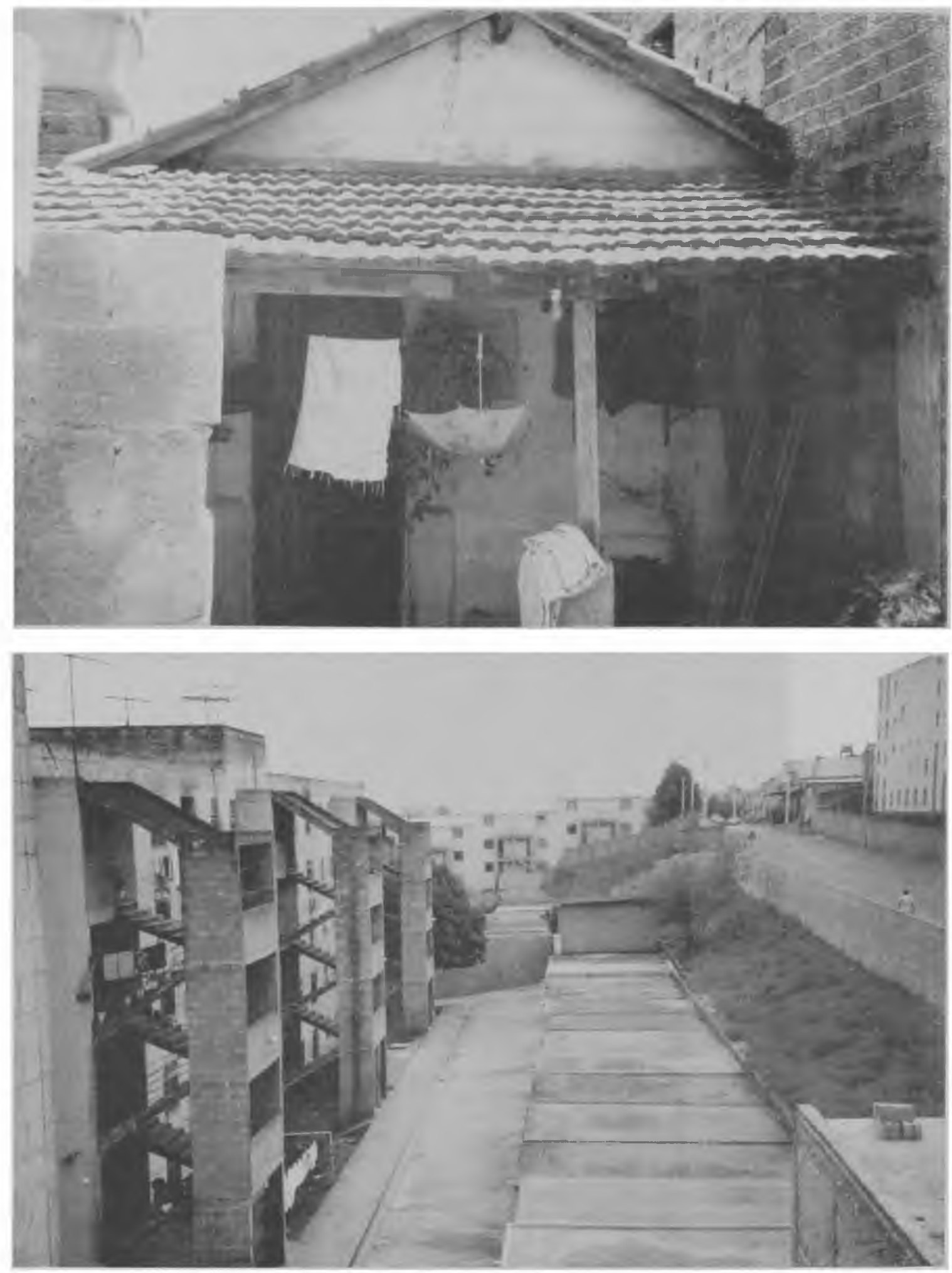

Fotos 2 e 5: Para a criança, a casa não é apenas o lugar onde os objetos se inscrevem, mas também uma rede de afetos (Foto: Angelo Serpa). 
Esse universo desconhecido e ameaçador que é o espaço externo à casa é "suavizado" na representação gráfica de Tayane (Figura 6), com a introdução de elementos naturais "emoldurando" a fachada escura do prédio: nuvens, uma árvore, arbustos e o sol por detrás do prédio são coloridos em contraste à fachada marrom do edifício. Elementos naturais também estão muito presentes no desenho de Rodrigo ( 9 anos - Figura 8): o sol (com rosto e sorrindo) e nuvens (azul e vermelha!) aparecem aqui com destaque. O menino é maior do que a árvore, com frutos vermelhos e tronco lilás: aparece no desenho jogando bola e a bola parece estar amarrada no seu pé (o que pode querer indicar o movimento da bola para o alto ou expressar - de forma inconsciente - a sensação de falta de liberdade).

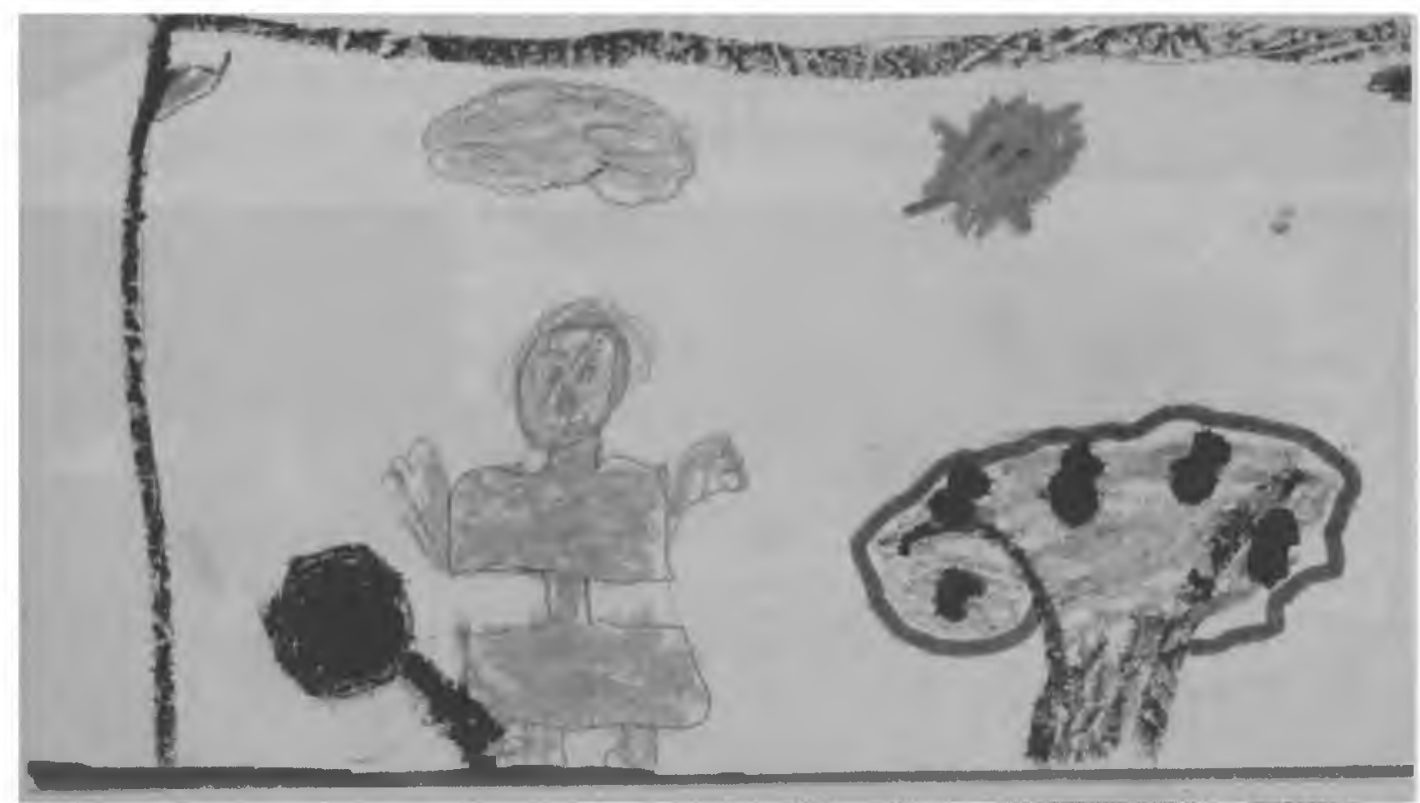

Figura 8: Jogo de bola (Rodrigo, 9 anos).

Rodrigo transforma a rua onde brinca no terreno baldio em frente à sua casa, onde os pais o proíbem de brincar (com o símbolo funcionando aqui mais uma veż como efeito compensador). O espaço "brincável" é delimitado no desenho 
por uma espécie de moldura, como numa foto. O menino brincando sozinho parece "preso", enquadrado no desenho. $\mathrm{O}$ meio fio entre a rua e o terreno baldio é o limite do espaço de brincar de Rodrigo (Fotos 6 e 7).
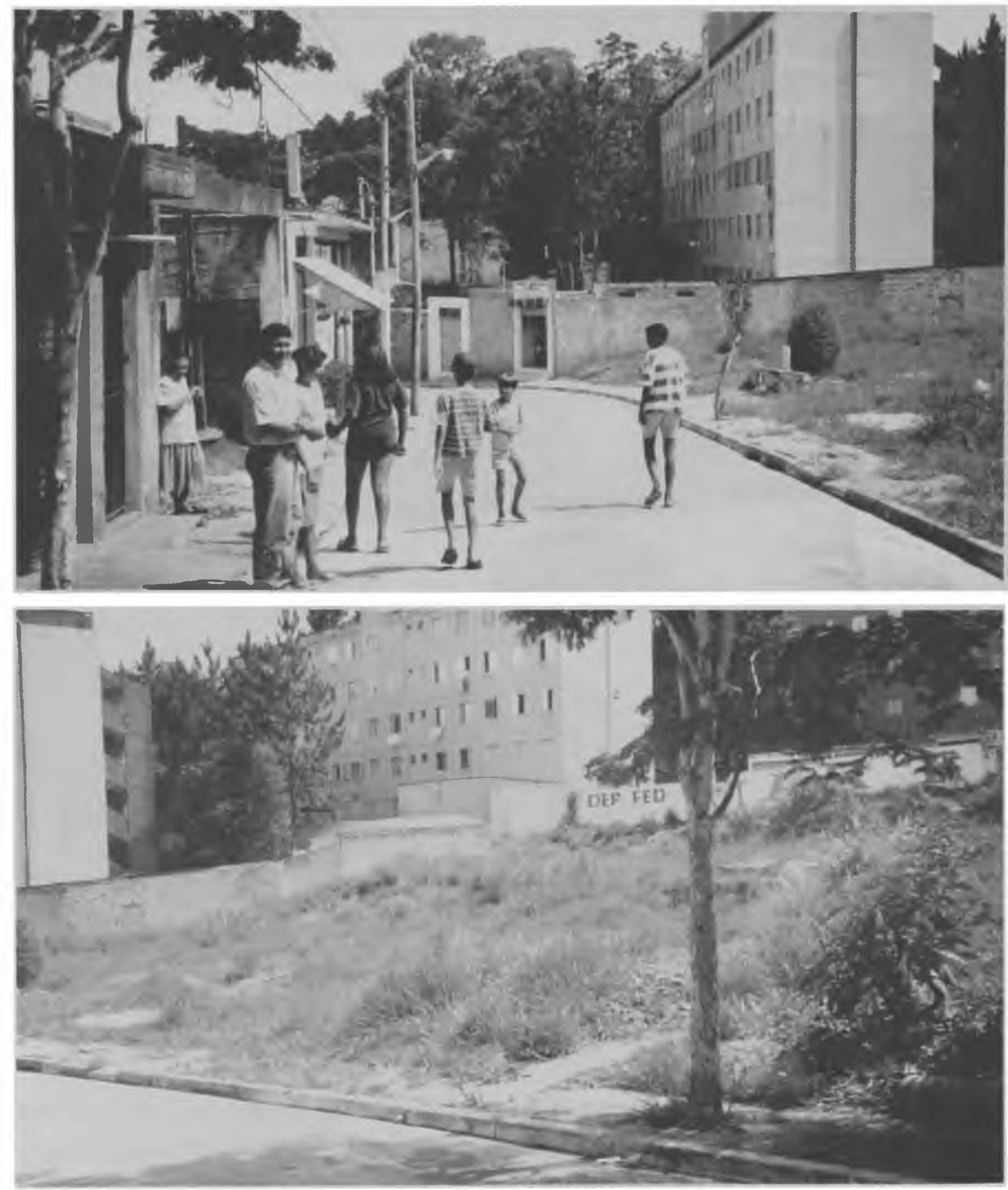

Fotos 6 e 7: Rodrigo transforma a rua onde brinca no lerreno baldio em frente à sua casa, onde os paiso prorbem de brincar (Fotos: Angelo Serpa). 
Observa-se que a percepção do espaço obedece na criança a critérios que não são propriamente métricos, mas afetivos. Não há a preocupação premente de respeitar as proporções dos objetos, uma vez que a criança thes atribui uma grandeza afetiva $^{17}$ A casa e o espaço extemo acabam funcionando, portanto, como projeção das angústias e das fantasias infantis.

Mapear o espaço vivido é tarefa complexa que exige tanto da criança, como do adulto, coordenação e aplicação prática das informações "espaciais" colhidas no cotidiano. Na verdade, um verdadeiro sistema de coordenadas é criado pelos indivíduo para a solução de "problemas espaciais" cotidianos (comop. ex. descobrir o melhor caminho a pé para a escola). A criança utiliza para a solução de tais problemas um sistema egocêntrico ${ }^{18}$, baseado nas suas próprias experiências e limitações corporais: ela mapeia o espaço em forma de caminhos isolados, lugares e pontos marcantes só são "gravados" e reconhecidos com base nestes caminhos. A criança parece incapaz de imaginar as relaçōes entre estes caminhos isolados e de conjugá-los num todo; não vê ainda a complexidade do espaço onde vive.

Este sistema egocêntrico de mapear o espaço fica claro no desenho de Abadia (9 anos - Figura 9), que representa a rua onde mora (e brinca) dando destaque à sua casa e também às casas de dois colegas de escola (Talita e Cleber). Alguns detalhes interessantes aparecem no desenho de Abadia, como o cruzamento em frente à casa de Talita, assim como o semáforo e os quebramolas na rua: fica claro que, para Abadia, as referências mais fortes são as casas dos seus melhores amigos e os meios de que dispõe para atravessar as ruas e chegar até eles. Note-se que nenhuma outra casa (ou prédio) é representada no desenho, como se na rua só existisse a sua e as dos dois colegas.

É somente com o desenvolvimento da criança que esse sistema egocêntrico vai sendo abandonado e substituído gradualmente por um sistema de coordenadas mais complexo, no qual ela constrói suas referências com base em pontos e lugares concretos, ao invés de tentar relacioná-los de forma egocêntrica 
consigo mesma. Em outras palavras, a criança deixa de ser o centro do universo para relacionar-se de forma mais construtiva e proveitosa com o espaço onde vive.

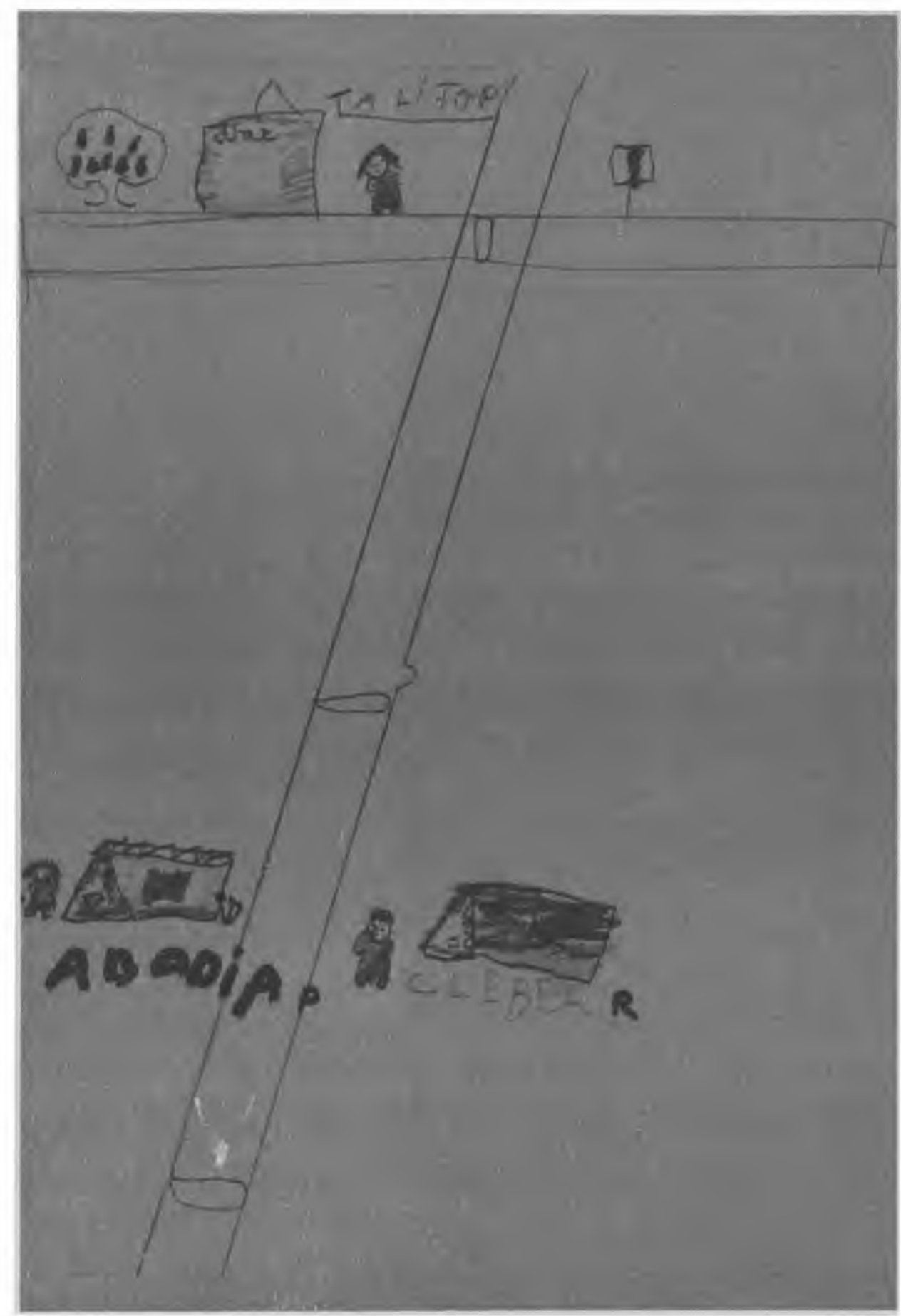

Figura 9: Mapeando o espaço cotidiano (Abadia, 9 anos). 


\section{A SEGREGAÇÃO ESPACIAL DO ATO DE BRINCAR: CONSEQÜÊNCIAS PARA O PLANEJAMENTO URBANO}

"A grande problemática dos centros urbanos é onde colocar a criançada." É assim que dona Ana Regina Spinardi (Foto 4), 36 anos, mãe de Bruno (Figura 3), resume, em tom de desabafo, a posição da maioria dos pais e mães entrevistados. Ela reconhece que por causa do "medo" não deixa nunca seus três filhos saírem sozinhos: "Tem vários tipos de medo. A questão do trânsito, essa violência presente que é o assalto, o roubo e também a questão das drogas. Já existia drogas em Itaquera, mas depois do confinamento nos prédios isso se tornou mais presente."

Por falta de tempo ou pela falta de opções de lazer no bairro, as crianças acabam passando o dia entre a escola e a casa. "Passear mesmo é muito difícil. As crianças acordam às nove horas, tomam café e já vão prá escola. Quando chegam já é quase final de tarde", diz dona Maria da Penha Cunha da Silva, 27 anos, mãe de Rodrigo (Figura 8). Rodrigo acaba brincando a maior parte do tempo na rua em frente a sua casa, onde não há muito movimento de carros.

"Para percebero espaço e se apropriar do meio ambiente em que vive, o ser humano precisa interagir com as estruturas (materiais e sociais) e com os objetos que compõem este meio. Domínio espacial requer, portanto, um aprendizado constante e interativo" 19. Como se toma, na maior parte dos casos, um espaço proibido, o entomo da casa acaba sendo mais desconhecido para a criança do que os espaços e lugares mais distantes, intermediados de forma indireta pela televisão, pelo cinema e pelos gibis de histórias em quadrinhos. ${ }^{20}$ É assim que o espaço adquire para a criança e o adolescente um caráter virtual: "As minhas crianças ficam brincando aqui dentro de casa mesmo, ou na areazinha aqui (...) Elas ficam brincando na escada de boneca. Às vezes eu pego as duas e elas ficam andando de bicicleta aqui na rua." (Dona Mirian de Oliveira Araújo, 32 anos, mãe de Tayane - Figura 6 e Fotos 5 e 8). 


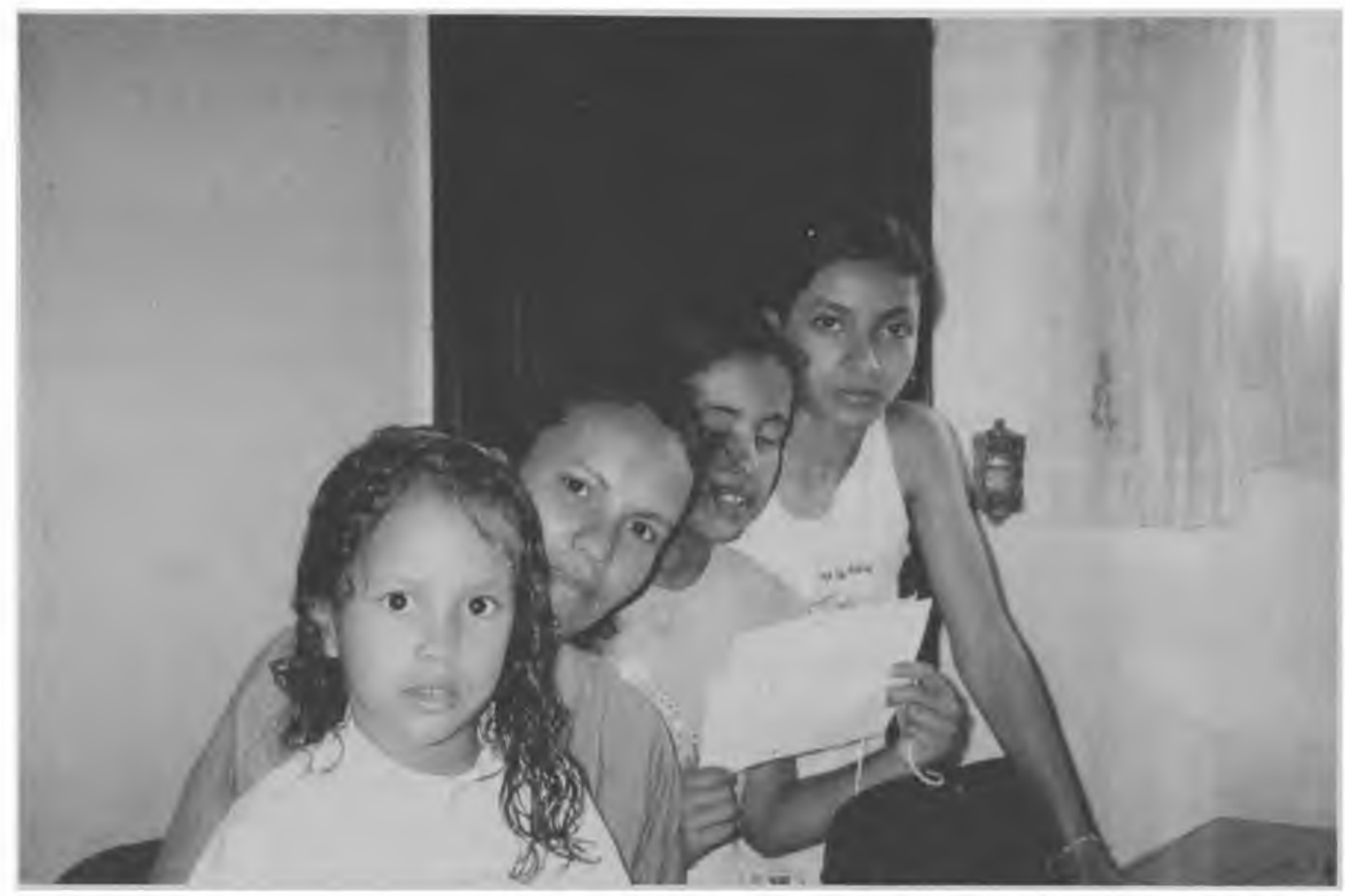

Foto 8: "As minhas crianças ficam brincando aqui dentro de casa mesmo" (Foto: Angelo Serpa).

Mas quais podem ser as conseqüências da segregação espacial do ato de brincar? Com base nos desenhos analisados aqui, o que se constata é que isso não parece afetar o desenvolvimento da criança, tanto no ato de brincar propriamente dito, como na representação gráfica do espaço vivido no cotidiano. $O$ jogo lúdico parece obedecer ao desenvolvimento gradual proposto por Piaget, com o aparecimento da regra em detrimento do exercício sensório-motor e do símbolo, compatível com a idade das crianças entrevistadas (7-9 anos). A segregação espacial do ato de brincar parece ocasionar, no entanto, uma certa renitência do símbolo deformante, que para Piaget já deveria estar totalmente superado nesta fase do desenvolvimento da criança. O símbolo deformante aparece aqui como compensação para o espaço "real", para o espaço potencialmente interessante para o jogo lúdico, mas sujeito às proibições dos pais, transformado em espaço virtual pela representação gráfica idealizada. 
"A criança precisa de mais espaço para o jogo lúdico"z!. Convém ressaltar que o problema não se resume apenas à quantidade dos espaços disponíveis para o jogo, mas apresenta também um aspecto qualitativo: ${ }^{22}$ na Europa, é crescente a crítica às áreas de recreação infantil planejadas. Tais áreas parecem servir apenas para manter o status quo vigente, valorizando a engenharia de trânsito e o automóvel, em detrimento da criança e do jogo lúdico. Verdadeiros guetos, os parques infantis parecem se contentar apenas em suprir as necessidades de movimento da criança, sem exigir muito de sua criatividade e capacidade de superar problemas concretos, parecidos com as "engenhocas" criadas para "distrair" os hamsters em uma gaiola.

As áreas de recreação infantil planejadas parecem ser, porém, a principal reivindicação dos paise mães entrevistadosem Itaquera, o que mostra a "internalização" dos princípios de segregação espacial da criança, ditados pelo planejamento urbano tradicional: "Nessa praça aqui perto de casa não tem brinquedo. Ali no começo era bonitinho, verde, tinha bastantes brinquedos. $A$ praça Raul Seixas, que inauguraram recentemente na Cohab, é muito bonita, lá é verdinho, tem muitos brinquedos também" (Dona Maria de Paiva, 31 anos, mãe de Juliana - Figura 1 e Fotos 1 e 2). Dona Mirian de Oliveira Araújo vai mais longe e, além dos "muitos brinquedos", também "cercaria a área para as crianças, principalmente as pequenininhas": "Porque não adianta você fazer uma praça aqui e ter que estar correndo para pegar a crianca, para ela não ir para a rua. Assim, nem a criança fica tranqüila, nem a mãe fica tranqüila".

O jogo lúdico é, no entanto, um aprendizado "processual" que não se contenta com guetos, mas exige espaço para acontecer. Como dito anteriormente, a criança precisa da possibilidade de exercer o seu direito de brincar, aqui, agora e por toda a parte. Programas, como o das ruas de lazer, implantadas em São Paulo na década de $70^{23}$, podem servir de ponto de partida para a criação de espaços de brincar no entorno habitacional da criança. O mapeamento de espaços livres potenciais para o jogo 
lúdico, como os terrenos baldios, existentes em profusão em Itaquera, eque poderiam também ser incorporados ao programa das ruas de lazer ${ }^{24}$, possibilitaria a ampliação do espectro de opções para o jogo lúdico no bairro.

Tais programas poderiam ainda ser incrementados com a organização de festas, festivais de teatro infantil e a prática organizada de esportes e gincanas. Aliás, é essa também uma das principais reivindicações dos pais e mães entrevistados: "Oque tinha que ter nessas praças era um centro desportivo infantil, para a prática de esporte olímpico" (Sr. Paulo Fabiano, 46 anos, pai de Lucinéia - Figura 2). Já dona Marisa (Foto 3), esposa do Sr. Paulo, sonha com a "apresentação de cantores-mirins para divertir as crianças": "Também poderia ter teatro ou professores para ensinar os pequenos a pintar ao ar livre. As nossas crianças não têm com que brincar, ficam correndo de lá para cá, como baratas tontas".

É conveniente ressaltar ainda a importância desses terrenos baldios, que não necessitam nada além de limpeza e saneamento, mas que podem assumir para a criança "ares de mistério e aventura" $E$, por que não deixar por ali, às vistas das crianças, um pouco de madeira, ferramentas, pregos? Por que não estimular os jogos de construção de casas em árvores? Por que não ressaltar o caráter provisório daquele espaço através de intervenções artísticas? Por que não plantar ali árvores frutíferas e fornecedoras de sombra para as mães e de madeira para as crianças?

Note-se que falo aqui da revigoração de espaços "mortos" (e não falo aqui apenas dos terrenos baldios, mas também das praças e ruas de lazer): com a volta da população do entorno habitacional, esses espaços talvez possam num futuro próximo ganhar vida nova, como no espaço virtual (ideal) representado nos desenhos das crianças, que analisamos juntos neste artigo. 


\section{UMA CIDADE POR REFAZER?}

"O que percebemos, pelas conversas com pessoas simples das Cohabs, é que quem deveria estar lutando pela melhoria das condições de transporte e moradia não o faz de maneira ordenada. Está mais interessado, e com justa razão, em obter o necessário para a alimentação e educação de sua família. Salvo raras exceções, o que se vê é a negação da origem rural, por pressão preconceituosa da sociedade, quando o trabalhador passa a ser um 'novo paulistano' e a fazer parte do mundo de cimento e asfalto." 25

A segregação do universo infantil no contexto urbano não pode ser vista como um fato isolado. A construção de grandes conjuntos habitacionais populares, nas franjas periféricas das grandes cidades, decorre da política oficial implementada pelo BNH e pelas Cohabs a partir da década de 70 . Com projetos padronizados e de execução precária, esses "conjuntos-pacote" são constituídos por edifícios isolados, geralmente dispostos paralelamente entre si e sem nenhuma relação com o entorno.

Assim, "a expansão da mancha urbana e a ocupação do espaço periféricona cidade de São Paulo (...) decorrentes, a partir de um dado momento histórico, da combinação entre a casa precária autoconstruída ou autogerenciada pelos moradores e o loteamento popular freqüentemente irregular ou clandestino ${ }^{\prime 26}$, dá lugar à cidade "oficial" planejada, sem a participação dos futuros moradores na sua concepção. Esse processo de expansão e ocupação espontâneas, que resultou em práticas urbanísticas peculiares e que configurou, ao longo de décadas, "um desenho urbano característico ao processo de urbanização do município $^{\prime 27}$, é negado, portanto, por uma prática de planejamento urbano autoritária e excludente.

A aplicação dos conceitos e instrumentos de sintaxe espacial, desenvolvidos pelo arquiteto inglês Bill $\mathrm{Hillier}^{28}$, em áreas de tecido tradicional (centro de Itaquera) e naquelas planejadas 
pela prefeitura e governo do Estado (conjunto habitacional José Bonifácio, no mesmo bairro ${ }^{29}$ mostraram que, mesmo nestas últimas, a população interfere e se apropria do espaço, redefinindo as relações público/privado. Criam-se dessa forma novas hierarquias urbanas, de espaços melhor categorizados e que expressam uma maior identidade territorial. É a busca de um "arquétipo" coletivo de cidade: "Os espaços tomados ao que antes era público são percebidos agora quase como um tecido tradicional de cidade com quarteirões, ruas, praças, largos, etc ${ }^{30}$."

No conjunto habitacional José Bonifácio, a privatização de espaços considerados no projeto original como "públicos" resulta do fato de que os mutuários-em grande parte por pressão da própria prefeitura no sentido de legalizar e regularizar as áreas condominiais - cercam o lote do prédio depois de quitarem o imóvel junto à Cohab. Observa-se que as camadas menos favorecidas da população acabam assumindo o "ideal das elites": o prédio isolado no lote.

"Os padrões de organização social dos mais ricos são reproduzidos, como todos os demais, típicos das elites sociais, de um modo reduzido, e na medida do possível, por todas as camadas sociais. A população de um conjunto habitacional, Cohab, recodifica e transforma seus espaços livres, seguindo os arquétipos das classes mais ricas, criando ao seu modo cercas, pátios, guaritas, jardins e estacionamentos ${ }^{31}$."

No conjunto José Bonifácio, cercado os prédios de apartamentos, começa a disputa interna pela ocupação e apropriação do espaço privatizado. Ganha em regra quem grita mais alto nas assembléias dos condôminos. $O$ que prevalece são os estacionamentos, com garagens e lojas de construção precária: ocupam $41 \%$ da área total. No entanto, a percentagem de áreas ajardinadas e terrenos baldios nos espaços internos aos prédios é alta, cerca de $29 \%$.

Observa-se que a disputa não é só interna a cada prédio, mas também uma disputa entre prédios por mais espaço. Antigos 
acessos e sobras de terrenos não utilizados pela Cohab foram, ao longo do tempo, simplesmente "incorporados" pelos prédios vizinhos. São justamente essas edificações com mais "terreno" que apresentam espaços livres melhor hierarquizados, com jardins frontais e/ou laterais.

Nos prédios com menos espaço, a tendência é a redução e, em alguns casos mais radicais, a total eliminação das áreas ajardinadas no interior das edificações:

"Esse apartamento é próprio. Meus pais levaram 25 anos para pagar. Antes não tinha muro, só grade. Só depois os moradores se reuniram e foram cercando. Assim ficou mais privativo. Se for me falar que é por conta da segurança, não é. $O$ portão fica aberto direto. É para limitar o terreno, entendeu? Tem um jardim na frente do prédio, mas os moradores estão acabando com ele. A gente tinha uma área maior de jardim, aí derrubaram uma árvore e levaram uma multa. Aí diminuíram o jardim para fazer outra garagem. A gente vai ficar sem área verde aqui no prédio. Já teve muita briga, agora o pessoal acalmou. Porque são 40 moradores, em outros prédios, 60, e não tem espaço para todos!." (Fátima Regina dos Santos, 30 anos, moradora do conjunto José Bonifácio, em Itaquera).

Os terrenos baldios, "incorporados" aos prédios vizinhos e cercados, ou apresentam declividade muito alta e são abandonados pelos moradores, ou servem como varal de roupas coletivo. Nas casas-padrão da Cohab, cerca de $15 \%$ das unidades construídas no conjunto José Bonifácio, os jardins frontais e os quintais desaparecem, dando lugar a garagens e a cozinhas ampliadas.

A aplicação do método de Hillier permitiu também a distinção de eixos de circulação de controle predominantemente local (pelos moradores) e outros de controle global (pelo visitante/ passante) nas duas áreas estudadas ${ }^{32}$. Pode estar aqui a chave para um planejamento mais humano dos "espaços de brincar" 
Minhas pesquisas e observações nos bairros de Itaquera, Guaianazes e São Miguel Paulista me convenceram que o jogo lúdico e a apropriação do espaço urbano pela criança são determinados (limitados):

- Pelo uso do automóvel, cada vez mais disseminado também entre os moradores de bairros periféricos;

- pela não aceitação, por parte dos pais das crianças, de espaços de brincar menos rígidos e formais;

- pelo medo da violência crescente.

Mais importante que o mapeamento de espaços livres potenciais para o jogo lúdico, é a busca da integração destes espaços por eixos de circulação de controle predominantemente local. A idéia é a criação de um "sistema" integrado de espaços de brincar, com a implementação de "corredores" seguros para a circulação das crianças na escala do bairro.

A identificação destes eixos locais pode permitir a transformação imediata dessas vias em "ruas de lazer", com a retomada do programa, criado na década de 70 em São Paulo. Desnecessário afirmar que a retomada de tais programas requer diálogo constante com os moradores e usuários, de modo a contemplar, no detalhamento dos projetos, as características e especificidades de cada bairro.

Parece utópico, mas a implementação de um sistema integrado de espaços de brincar, poderá reproduzir, nos bairros periféricos, as relações de intimidade e vizinhança observadas no meio rural ou em cidades menores, onde o espaço da rua transformase em extensão da casa.

O ideal de transformação expresso pelas crianças encontra na fada do desenho de Talita (Figura 4 ) sua melhor tradução: "Mestra da magia, a fada simboliza os poderes paranormais do espírito ou as capacidades mágicas da imaginação. Ela opera as mais extraordinárias transformações e, num instante, satisfaz ou 
decepciona os mais ambiciosos desejos. Talvez por isso ela represente a capacidade que o homem possui para construir, na imaginação, os projetos que não pôde realizar. ${ }^{133}$

\section{AGRADECIMENTOS}

Meus sinceros agradecimentos à professora Simone Coelho Gomes, que permitiu a realização da pesquisa junto às crianças de sua classe na Escola Benedito Calixto, e a psicóloga Anacélia Fornes Mateucci, que ajudou na análise dos desenhos.

\section{NOTAS}

(1) A teoria de Piaget diferencia, de acordo com Pinard e Sharp ("I.Q. and point of view", Psychology Today, jun. 1972, p. 65-68 and 90), quatro fases principais:

- Fase sensório-motora (do nascimento até um ano e meio ou 2 anos): $\mathrm{O}$ período em que $o$ ato de pensar se traduz em ações concretas, antes do aparecimento da fala.

- Fase do pensar simbólico (de um ano e meio ou 2 até 7 anos): A criança é capaz de usar símbolos para transformar ações em pensamentos.

- Fase do pensar concreto (dos 7 aos 11 ou 12 anos): A criança é capaz de realizar operações matemáticas mais complexas como adição e multiplicação, classificar e correlacionar objetos.

- Fase do pensar formal (dos 11 ou 12 aos 14-15 anos): O jovem nãoestámais tão ligado aos objetos concretos e é capaz de argumentar e levantar hipóteses.

(2) PIAGET, J. and INHELDER, B. The child's conception of space. London: Routledge and Kegan Paul, 1956.

(3) PIAGET, J. citado por DOWNS, R.M. \& STEA, D.. Kognitive Karten: Die Welt in unseren Köpfen. New York: Harper \& Row Publishers, 1982, p. 263.

(4) "Por volta das 11 horas, ele passou em casa e disse que iria dar mais uma volta de bicicleta e voltava rápido. Às $11 \mathrm{~h} 20$, minha mãe começou a se preocupare a procurar. Na hora doalmoço, eu costumava ir em casa, ol hava os caderninhos dele e esperava oônibus da escola vir buscá-lo. Mas, aquele dia, ele não estava lá me esperando. Enunca mais tivemos a menor pista do meu filho. Ninguém viu. Não acharam uma roupa, nem a bicicleta. Não encontraram nenhum corpo" (Depoimento de Arlete Caramês à jornalista 
Dagmar Serpa, Reportagem "Mães em Desespero", Revista Marie Claire, São Paulo: Editora Globo, fev. de 1995, p. 35-39).

(5) NOHL, W. Streifräume statt Spielplätze: Zur Planung konvivialer Spielumwelten. In: Das Gartenamt, Berlin-Hannover, 1990, p. 212.

(6) PIACET, J. A formação do símbolo na criança. 3. ed. Rio de Janeiro: Guanabara Koogan, 1978, p. 144.

(7) Idem, Ibidem.

(8) Idem, Ibidem, p. 146.

(9) Idem, Ibidem, p. 144 e 147.

(10) Idem, lbidem, p. 180.

(11) Idem, Ibidem, p. 144 e 147.

(12) Idem, Ibidem, p. 182.

(13) LUQUET Le dessin enfantin. Alcan, citado por MEREDIEU, F. de. $O$ desenho infantil. Editora Kultrix, São Paulo, 1974, p. 22.

(14) MEREDIEU, F. de. O desenho infantil. São Paulo: Kultrix, 1974, p. 58-59.

(15) "A criança vive os objetos em simbiose uns com os outros; afetivamente, ela não os separa: a casa é percebida através das experiências múltiplas que provoca, indissociável dos personagens e objetos que ela contém" (Florence de Meredieu, $O$ desenho infantil, 1974, p. 24).

(16) MEREDIEU, F. de. O desenho infantil. São Paulo: Kultrix, 1974, p. 51.

(17) Idem, Ibidem, p. 43.

(18) DOWNS, R. M., STEA, D. Kognitive Karten: Die Welt in unseren Köpfen. New York: Harper \& Row Publishers, p. 266, 1982.

(19) Idem, Ibidem, p. 294.

(20) "Outrora, na época em que a maioria dos homens vivia ainda para o essencial, no quadro da auto-subsistência aldeã, a quase totalidade de suas práticas se inscrevia, para cada um deles, no quadro de um único espaço, relativamente limitado: o "terroir" da aldeia e, na periferia, os territórios que relevam das aldeias vizinhas. Além, começavam os espaços pouco conhecidos (...) Hoje, as coisas mudaram muito e a massa da população se refere, mais ou menos conscientemente, através de práticas as mais diversas, a representações do espaço extremamente numerosas que permanecem, na maioria dos casos, bastante imprecisas (...) Hoje, é sobre distâncias bem mais consideráveis que, a cada dia, as pessoas se deslocam (...) só se conhecem bem dois lugares, dois bairros (aquele onde se dorme e aquele 
onde se trabalha); entre os dois existe não exatamente todo um espaço, mas, um tempo, otempo de percurso" (Lacoste, Yves. A Geografia - Isso serve, em primeiro lugar para fazer a guerra. São Paulo: Papirus, p. 43-46, 1985).

(21) SCHMIDT, R. Mehr Spielraum für Spielräume. In: Garten + Landschaft, n. 7/87, Munique, 1987, p. 42.

(22) "Não faltam espaços livres, o que falta é a chance de utilizá-los" (Lucius Burckhardt, Die Kinder fressen ihre Revolution, DuMont Buchverlag, Köln, 1985, p. 203).

(23) Entre fevereiro de 1976 e outubro de 1978 foram implantadas cerca de 188 ruas de lazer no município de São Paulo.

(24) "As razões que levaram os moradores das nossas áreas de estudo a reivindicar o lazer no espaço livre junto a suas residências, é compatível com a lógica da apropriação espacial em função da limitação de ordem etária dos usuários. Estes dados são resultantes da pesquisa feita para verificar a razão porque os moradores das ruas de lazer solicitaram o fechamento dominical do tráfego para a promoção do lazer. $50 \%$ dos entrevistados fazem alusão a falta de espaços livres para o lazer infantil e cerca de $13 \%$ referem-se a falta de local para o lazer na proximidade" (Nishikawa, Ayako. Espaços livres junto às habitações em São Paulo. São Paulo, 1984. Dissertação (Mestrado). Faculdade de Arquitetura e Urbanismo, Universidade de São Paulo.

(25) ID, L.: O que representa hoje em dia morar em São Paulo? In: Serpa, A., Chinelli Junior, N., Bicalho, L., Id, L. Vilas Operárias versus Conjuntos Habitacionais Populares, Memória de Referenciais Naturaise de Ambientação Regional. Trabalho final da disciplina AUP-826 “Mensagens Visuais Integradas", do curso de pós-graduação da FAUUSP, área de concentração Estruturas Ambientais Urbanas, São Paulo, 1988.

(26) GROSTEIN, M. D.: Uma cidade por refazer: a periferia paulistana. In: Revista USP, Dossiê Cidades, mar./abr./maio/1990, p. 35.

(27) Idem, Ibidem.

(28) HILLIER, B., HANSON, J. The social logic of space. Cambridge: Cambridge University Press. 1984.

(29) SERPA, A. Morfologia e apropriação dos espaços livres em Itaquera, São Paulo: Alguns conceitos e considerações, Anais do II ENCONTRO NACIONAL DE ENSINO DE PAISAGISMO EM ESCOLAS DE ARQUITETURA E URBANISMO NO BRASIL, 02 a 05.10.95, São Paulo: FAUUSP, 1995.

(30) RIGATII, D. Apropriação social do espaço público - Um estudo comparativo. Revista Paisagem e Ambiente, São Paulo: FAUUSP, n. 7, p. 166. 
(31) MACEDO, S. S. Espaços livres. Revista Paisagem e Ambiente - Ensaios. São Paulo: FAUUSP, n. 7, 1995, p. 50.

(32) SERPA, A. Morfologia e apropriação dos espaços livres em Itaquera, São Paulo: Alguns conceitos e considerações, Anais do II ENCONTRO NACIONAL DE ENSINO DE PAISAGISMO EM ESCOLAS DE ARQUITETURA E URBANISMO NO BRASIL, São Paulo: FAUUSP, 1995.

(33) CHEVALIER, J., GHEERBRANT, A. Dicionário de símbolos. 8. ed. São Paulo: José Olympio Editora, 1992, p. 415-416. 